\title{
CONSOLIDAÇÁO DA PROPRIEDADE FIDUCIÁRIA POR CREDOR ESTRANGEIRO EM FAIXA DE FRONTEIRA
}

\author{
Eleandro Granja Costa Vanin e Hochmann ${ }^{1}$ \\ Centro Universitário Curitiba (UNICURITIBA)
}

\author{
André Lipp Pinto Basto Lupi ${ }^{2}$ \\ Centro Universitário Curitiba (UNICURITIBA)
}

\section{Resumo}

Este trabalho tem como propósito examinar a possibilidade da consolidação da propriedade fiduciária por credores estrangeiros em terras da faixa de fronteira brasileira, em vista da recente alteração empreendida pela Lei n. 13.986/2020 (Lei do Agro), especialmente em relação à Amazônia Legal. Em um primeiro momento, examinar-se-á a história da regulação da aquisição da propriedade rural por estrangeiros no ordenamento nacional. Em segundo lugar, o instituto da alienação fiduciária de bem imóvel em garantia será objeto de análise, tal como previsto na Lei n. 9.514/1997. Segue uma discussão sobre a faixa de fronteira no direito brasileiro: sua previsão normativa, funçôes e importância para o país. No quarto e último capítulo, objeto específico do trabalho, será examinada a possibilidade da consolidação do bem imóvel dado em alienação fiduciária pelo credor estrangeiro quando situado na faixa de fronteira, trazendo a discussão sobre seus reflexos para o desenvolvimento econômico-social destas regiōes. Em conclusão, defende-se que as recentes alteraçóes normativas permitiram a consolidação da propriedade em favor do credor estrangeiro. Foi empregado o método lógico-dedutivo, apoiado por pesquisa da bibliografia jurídica e de ciências sociais nacional e da legislação pertinente.

Palavras-chave: alienação fiduciária de coisa imóvel; estrangeiros; faixa de fronteira; Lei do Agro; Amazônia legal.

1 Doutorando em Direito pela Universidade de Marília (UNIMAR). Mestre em Direito pela UNIMAR. Mestrando em Direito pelo UNICURITIBA. Bacharel em Direito pela Universidade do Estado do Mato Grosso (UNEMAT). Tabelião de Protesto de Títulos em Belém-PA. Presidente do Instituto de Protesto de Títulos do Brasil, Seção Pará. ORCID: https://orcid.org/0000-0003-1835-5574 / e-mail: granja8519@gmail.com

2 Pós-Doutor em Ciências Jurídico-Privadas pela Universidade de Lisboa (ULISBOA). Doutor em Direito pela Universidade de São Paulo (USP). Bacharel e Mestre em Direito pela Universidade Federal de Santa Catarina (UFSC). Professor do Programa de Mestrado e Doutorado em Direito Empresarial e Cidadania do UNICURITIBA. Professor de Direito Empresarial na UFSC. Presidente da Comissão de Direito Empresarial da OAB/SC. ORCID: https:// orcid.org/0000-0001-5574-1736/ e-mail: https://orcid.org/0000-0001-5574-1736 


\section{THE POSSIBILITY OF CONSOLIDATION OF FIDUCIARY OWNERSHIP BY THE FOREIGNER CREDITOR IN LANDS OF THE BRAZILIAN BORDER ZONE}

\section{Abstract}

This work aims to examine the possibility of consolidation of fiduciary property by foreign creditors in lands of the Brazilian Border Zone, given the recent alterations by Federal Law no 13.986/2020 (Agrobusiness Act), especially with regard of the Legal Amazonia. In a first moment, the article describes the history of regulations concerning the acquisition of land by foreigners in Brazil. Afterwards, the institution of chattel mortgage will be analyzed, as provided in Federal Law no 9.514/1997. A discussion on the Brazilian Border Zone follows, regarding its legal provision, its functions and overall importance. In the fourth and last chapter, main object of this article, we analyze the possibility of consolidation of fiduciary ownership given as chattel mortgage by foreign creditors in the Brazilian Border Zone, bringing the discussion about its reflexes for the economic and social development of the regions. In conclusion, it is argued that the recent normative changes have allowed the consolidation of property in favor of the foreign creditor. The employed methodology is logical-deductive, supported by national research on National bibliographical legal and social sciences when necessary.

Keywords: Chattel mortgage as guarantee; foreigners; border zone; Brazilian Agrobusiness Act; Legal Amazonia. 


\section{Introdução}

A concepção tradicional de Estado elenca como seus três elementos fundamentais a soberania, o povo e o território (STRECK; MORAIS, 2014). Trata-se de uma definição que funciona bem em situaçôes clássicas: assim, segue a teoria tradicional, um povo institui um Estado para governar sobre um território. Contudo, a descrição se complexifica nas situações-limite, como no contato entre diferentes Estados ou, então, no convívio entre cidadãos de diversas nacionalidades no mesmo território, entre outras possibilidades. Subitamente, as respostas concebidas para o direito puramente interno passam a exigir qualificaçóes para dar conta da realidade. Em outras palavras, quando elementos nacionais distintos entram em contato, põem-se em evidência alguns problemas não facilmente respondidos pelas soluçôes teóricas tradicionais.

A dificuldade acima elencada, posta de lado como curiosidade interessante em décadas passadas, dominadas por um acentuado paradigma nacionalista e soberanista, torna-se cada vez mais premente no contexto de uma economia de mercado globalizada. Para dar apenas um exemplo, nota-se como o fluxo incessante de capitais, que não raro ultrapassa fronteiras nacionais, representa um aspecto de importância crucial para a economia contemporânea. É frequente que investidores de países ricos se estabeleçam nos países em desenvolvimento com o escopo de gerar riqueza em regióes com potencial econômico ainda pouco explorado; por sua vez, os países destinatários dos investimentos beneficiam-se da captação de recursos para o desenvolvimento de sua economia (KURTISHI-KASTRATI, 2013).

Uma das principais maneiras como o investimento estrangeiro ocorre consiste na oferta de crédito para os agentes econômicos do país em desenvolvimento. A oferta de crédito, por sua vez, depende em grande medida das garantias disponíveis para os credores em caso de inadimplemento dos mutuários. No Brasil, um marco essencial sobre o tema se deu com a instituição da alienação fiduciária de bens imóveis, a partir da Lei n. 9.514/1997. Esse diploma atraiu investimentos internacionais, na medida em que atribuiu mais segurança às garantias dos credores; além disso, contribuiu para a expansão do crédito para as classes menos abastadas. ${ }^{3}$

O presente artigo pretende abordar um tema que se situa exatamente nessa zona de intersecção entre economia globalizada, por um lado, e as limitaçóes da concepção tradicional da teoria do Estado, por outro. Procurar-se-á discutir

3 "Por se tratar de garantia especial, a alienaçẫo fiduciária constitui-se, portanto, em um estímulo à celebração de negócios, ficando os agentes econômicos mais seguros contra inadimplementos. Por isso ela seria importante fator de estímulo ao mercado, cujo funcionamento se dá naturalmente por meio de trocas voluntárias que são contratos" (TIMM; DRUCK, 2007, p. 10). Referência bibliográfica fundamental para o tema é a obra de CHALHUB (2006). 
a tratativa conferida ao estrangeiro pelo ordenamento brasileiro quanto ao tema da aquisição de propriedade imobiliária fiduciária, em particular nas terras pertencentes à faixa de fronteira nacional, em especial naquelas situadas na denominada Amazônia Legal (Mato Grosso, Rondônia, Acre, Amazonas, Roraima, Pará e Amapá) ${ }^{4}$ que experimentam os efeitos positivos e negativos da expansão do agronegócio. ${ }^{5}$

A razão motivadora da pesquisa é a aprovação da Lei do Agro - Lei n. 13.986 (BRASIL, 2020) - que reformou disposiçôes restritivas da Lei n. 5.709 (BRASIL, 1971) no tocante à aquisição de propriedade rural no Brasil por empresas brasileiras controladas por estrangeiros. O tema suscita dúvida quanto a sua extensão também à área caracterizada como faixa de fronteira pela Lei n. 6.634 (BRASIL, 1979). É que essa última lei, embora tenha tido parte da redaçáo alterada pela Lei do Agro, estabelece restriçôes especiais à aquisição de imóvel rural por pessoas naturais ou jurídicas estrangeiras, uma consequência possível do procedimento de alienação fiduciária no caso de inadimplemento do devedor-fiduciante. A questão, portanto, aparenta representar um caso de antinomia normativa.

Assim, num primeiro momento o artigo se deterá sobre a história do regramento referente à aquisição de imóvel rural por estrangeiros. Em seguida, abordar-se-á o instituto da alienação fiduciária de bem imóvel, tal como regulado pela Lei n. 9.514 (BRASIL, 1997). Para além das particularidades legislativas da alienação fiduciária, analisa-se também sua dinâmica a partir da ciência econômica. Já a terceira parte abordará aspectos geográficos e jurídicos da faixa de fronteira no Brasil, tal como instituída pela Lei n. 6.634 (BRASIL, 1979). Por fim, a quarta e última parte do artigo abordará a pergunta central deste estudo: é possível no ordenamento jurídico atual a consolidação da propriedade fiduciária por estrangeiros na faixa de fronteira brasileira? Será o caso de analisar em detalhe algumas das principais linhas de argumentação possíveis para respondê-la. Paralelamente, também se questiona sobre os reflexos positivos e negativos de termos investimentos estrangeiros em faixa de fronteira, em especial na Amazônia Legal.

Um estudo do gênero justifica-se em vista da importância da concessão de crédito para a atividade agropecuária na economia brasileira. A depender da resposta haurida no presente artigo, pode-se abrir margem a uma nova fonte de financiamento privado para milhões de brasileiros que detenham bens imóveis na faixa de fronteira. Ainda, tendo em vista a novidade do tema, não parece ter havido

4 A definição do território englobado pela Amazônia Legal consta da Lei n. 5.173 de 27 de outubro de 1966: "Art. $2^{\circ}$ A Amazônia, para os efeitos desta lei, abrange a regiāo compreendida pelos Estados do Acre, Pará e Amazonas, pelos Territórios Federais do Amapá, Roraima e Rondônia, e ainda pelas áreas do Estado de Mato Grosso a norte do paralelo de $16^{\circ}$, do Estado de Goiás a norte do paralelo de $13^{\circ}$ e do Estado do Maranhão a oeste do meridiano de 440". 5 A respeito dos benefícios do agronegócio, sobre a renda e o IDH, e a menor importância do fator terra para a produção, nessa região vide Prates e Bacha (2010). 
até o momento estudo pormenorizado sobre o assunto (embora especialistas na matéria já se tenham atentado para a existência da problemática), ${ }^{6}$ o que ressalta o ineditismo de uma análise verticalizada sobre as questôes aqui discutidas.

Para o desenvolvimento do estudo, utilizou-se do método lógico-dedutivo. Partiu-se, sobretudo, dos textos legais e sua interpretaçáo dogmática, para validá-la com apoio de pesquisa doutrinal (i.e., de bibliografia jurídica) e de críticas oriundas de outras searas das ciências sociais aplicadas.

\section{Aquisição de imóvel rural por estrangeiros: notícia histórica}

Costuma-se indicar no art. 153 da Constituição de Weimar a origem da limitação do caráter absoluto dos direitos reais privados, mediante a célebre expressão alemã "Eigentum verpflichtet" (a propriedade obriga).?

Referida limitação inaugurada pela Constituição de Weimar relacionava-se mais a questôes referentes à afirmação dos direitos sociais e à funcionalização da propriedade em favor de interesses metaindividuais, em iniciativa inspirada em parte pela Encíclica "Rerum Novarum" do Papa Leão XIII. ${ }^{8}$ Mas nem toda limitação ao livre uso da propriedade tem necessariamente esse escopo. É costumeiro vislumbrar-se no regime jurídico atinente à propriedade privada dos bens imóveis uma matéria de interesse estratégico para qualquer país, haja vista a profunda interrelação entre terra e alimentação, habitação, estrutura fundiária e segurança nacional. Não por outro motivo, os Estados nacionais costumam regular com cautela a aquisição de bens imóveis por cidadãos ou agentes econômicos estrangeiros.

A questão da limitaçáo da titularidade dos direitos reais por estrangeiros no direito brasileiro se trata de matéria já antiga na história legislativa brasileira. Um primeiro momento da temática verifica-se no art. 153, $\$ 34$ da Emenda Constitucional n. 1 (BRASIL, 1969b). ${ }^{9}$ Nos termos desse dispositivo, o Estado estaria autorizado a estabelecer limitaçóes e exigências para a aquisição da propriedade rural tanto por brasileiros quanto por estrangeiros residentes no Brasil, tendo em vista os valores da integridade do território, a segurança nacional e a justiça social.

Também sob a égide da EC n. 1/1969, instaurou-se o marco legislativo ainda em vigor a respeito do tema: a Lei n. 5.709 (BRASIL, 1971). É o diploma que prevê a regulação expressa dos casos de aquisição de imóvel rural por pessoa

6 Por exemplo, cf. FREITAS, 2020.

7 Cf. Sarlet (2019).

8 Cf. Cury (1998, p. 83-104).

9 Art. 153, \$ 34: "A lei disporá sobre a aquisiçăo da propriedade rural por brasileiro e estrangeiro residente no País, assim como por pessoa natural ou jurídica, estabelecendo condiçóes, restriçóes, limitaçóes e demais exigências, para a defesa da integridade do território, a segurança do Estado e justa distribuição da propriedade”. 
estrangeira. A racionalidade da lei não obedece à lógica tradicional de liberdade implícita ao direito privado, disciplinando especificamente as maneiras como os cidadãos estrangeiro ${ }^{10}$ poderão adquirir imóveis rurais no Brasil. ${ }^{11}$

Entre as várias limitaçôes previstas no âmbito da Lei n. 5.709 (BRASIL, 1971), encontra-se a vedação à aquisição de imóveis rurais superiores a 50 módulos de exploração indefinida, em área contínua ou descontínua (art. $3^{\circ}, \mathbb{1}$ ), a necessária submissão a regulamento do Executivo para a aquisição de imóvel com área compreendida entre 3 e 50 módulos (art. $3^{\circ}, \$ 2^{\circ}$ ), a necessidade de assentimento prévio da Secretaria-Geral do Conselho de Segurança Nacional nos casos de aquisição de imóvel situado em área "considerada indispensável à segurança nacional” (art. 7o), o registro da aquisição por escritura pública ser da essência do ato (art. $8^{\circ}$ ), bem como a previsão de um cadastro especial das terras nos Cartórios de Registros de Imóveis (art. 10), com remissão trimestral à Corregedoria de Justiça dos Estados e ao Ministério da Agricultura (art. 11). A faixa de fronteira veio a ser delimitada pela Lei n. 6.634 (BRASIL, 1979a), com extensão de 150 quilômetros. $^{12}$

Tendo entrado em vigor na época do regime militar, a Lei n. 5.709 (BRASIL, 1979b) necessitou passar por um exame de controle de constitucionalidade, tendo em vista a aprovação da Constituição da República de 1988 (BRASIL, 1988). É fato que a nova Constituição prevê a necessidade de regulação e limitação da aquisição ou do arrendamento de imóveis rurais por pessoas físicas ou jurídicas estrangeiras em seu art. $190 .{ }^{13}$ A previsão do artigo constitucional, contudo, não deixou de suscitar dúvida quanto a sua compatibilidade com o conteúdo substantivo da referida Lei.

A questão teve sua importância ainda mais acentuada quando o art. 23 da Lei n. 8.629 (BRASIL, 1993) (promulgada, portanto, já na vigência da Constituição de 1988) regulou a hipótese de arrendamento por estrangeiros, fazendo remissão justamente à Lei n. 5.709 (BRASIL, 1971). O Congresso Nacional, ao fazê-lo, acabou por ratificar entendimento em favor de sua legalidade diante do novo ordenamento constitucional..$^{14}$

10 Situação peculiar e digna de nota diz respeito ao cidadão português, que possui tratamento privilegiado na aquisição de imóvel rural, eis que dispensa-se a obtenção de autorização quando observados os seguintes requisitos: a) nấo se localize o imóvel em área indispensável à segurança nacional; b) tenha residência regular no Brasil; e c) haja reciprocidade de tratamento. Tal tratamento não é automático, dependendo de reconhecimento pela autoridade competente.

11 Art. $1^{\circ}$ : "O estrangeiro residente no País e a pessoa jurídica estrangeira autorizada a funcionar no Brasil só poderāo adquirir imóvel rural na forma prevista nesta Lei”.

12 "Art. $1^{\circ}$. - É considerada área indispensável à Segurança Nacional a faixa interna de $150 \mathrm{Km}$ (cento e cinquenta quilômetros) de largura, paralela à linha divisória terrestre do território nacional, que será designada como Faixa de Fronteira".

13 Art. 190: "A lei regulará e limitará a aquisição ou o arrendamento de propriedade rural por pessoa física ou jurídica estrangeira e estabelecerá os casos que dependerão de autorização do Congresso Nacional”.

14 Art. 23: "O estrangeiro residente no País e a pessoa jurídica autorizada a funcionar no Brasil só poderăo arrendar imóvel rural na forma da Lei n. 5.709, de 7 de outubro de 1971. $\$ 1^{\circ}$ Aplicam-se ao arrendamento todos os limites, restriçôes e condiçôes aplicáveis à aquisiçăo de imóveis rurais por estrangeiro, constantes da lei referida no caput deste artigo". 
Suscitou-se, em tais condiçóes, o exame da constitucionalidade do art. $1^{\circ}, \mathbb{S}$ $1^{\circ}$ da Lei n. 5.709 (BRASIL, 1971), que conferia às pessoas jurídicas brasileiras controladas por estrangeiros o mesmo regramento conferido aos estrangeiros residentes no Brasil ou às pessoas jurídicas estrangeiras em funcionamento no Brasil. O exame iniciou-se pela Consultoria-Geral da União, órgão da Advocacia-Geral da União encarregado de produzir pareceres para o assessoramento jurídico do Presidente da República. ${ }^{15}$

O primeiro parecer a respeito do tema foi o GQ-22, de $1994 .{ }^{16} \mathrm{Nele}$, o Advogado-Geral da União Geraldo Quintão consignou que o art. $1^{\circ}, \$ 1^{\circ}$ da Lei n. 5.709 (BRASIL, 1971) ${ }^{17}$ não teria sido recepcionado pela Constituição de 1988 por conta do teor do art. 171, I, da nova Carta. Para justificá-lo, a Advocacia-Geral da União (AGU) entendeu (BRASIL, AGU, 2010) que o conceito constitucional de empresa brasileira, ainda que com controle acionário de estrangeiros, não admitia as várias restriçóes à aquisição ou ao arrendamento de imóveis rurais no Brasil previstas na Lei n. 5.709 (BRASIL, 1971), do que decorreria sua inconstitucionalidade.

Contudo, o art. 171 da Constituição foi revogado pela Emenda Constituição n. 6/1995, o que suscitou nova atuação da AGU para examinar a questão da constitucionalidade daquela Lei. O exame redundou no Parecer GQ-181, de 1998 (BRASIL, AGU, 1998). Nesse documento, a AGU entendeu ser impossível interpretar que o art. $1^{\circ}, \$ 1^{\circ}$ da Lei n. 5.709 (BRASIL, 1971) teria sido repristinado pela Emenda Constitucional n. 6/1995, de modo tal que retomasse vigência jurídica. ${ }^{18}$ Portanto, uma vez mais afirmou-se o entendimento pela inconstitucionalidade do artigo.

O tema foi levado novamente a exame da Advocacia-Geral da União em 2010, quando da publicação do Parecer n. LA 01, de 19 de agosto de 2010 (BRASIL, AGU, 2010). Neste caso, o Advogado-Geral da União Luis Inácio Adams efetuou uma reversão do entendimento anterior. Para justificá-lo, entendeu que a restrição da aquisição de imóveis por estrangeiros não contrariaria o comando do art. 171 da Constituição Federal, que admitiria a previsão de restrições à atuação

15 É como dispóe o art. 10 da Lei Orgânica da Advocacia-Geral da Uniẫo (Lei Complementar n. 73/1993): "À Consultoria-Geral da Uniâo, direta e imediatamente subordinada ao Advogado-Geral da União, incumbe, principalmente, colaborar com este em seu assessoramento jurídico ao Presidente da República produzindo pareceres, informaçốes e demais trabalhos jurídicos que lhes sejam atribuídos pelo chefe da instituição".

16 Deixa-se de fazer remissão expressa ao Parecer n. GQ-22 pelo fato de ele não ter sido publicado pela própria AGU, como explica o Parecer n. GQ-181, que lhe sucedeu.

17 Art. $1^{\circ}$ : "O estrangeiro residente no País e a pessoa jurídica estrangeira autorizada a funcionar no Brasil só poderão adquirir imóvel rural na forma prevista nesta Lei. $\$ 1^{\circ}$ - Fica, todavia, sujeita ao regime estabelecido por esta Lei a pessoa jurídica brasileira da qual participem, a qualquer título, pessoas estrangeiras físicas ou jurídicas que tenham a maioria do seu capital social e residam ou tenham sede no Exterior".

18 "A Emenda Constitucional n. 6, de 15 de agosto de 1995, em seu art. 3º, revogou o art. 171 da Constituição. Essa revogação, pura e simples, qualquer que seja a interpretação que se dê, para outros fins, ao dispositivo constitucional, nâo tem o condão de repristinar a norma que se entendera revogada. Desse modo, continua revogado o $\$ 1^{\circ}$ do art. $1^{\circ}$ da Lei n. 5.709/71, permanecendo inalterada a conclusão do referido Parecer n. AGU/LA-04/94" (BRASIL, 1998). 
de empresas brasileiras controladas por estrangeiros (BRASIL, 2010). A restrição tampouco contrariaria princípios como a soberania nacional (art. 170, I, da Constituição), ou como a isonomia entre brasileiros e estrangeiros (art. $5^{\circ}$ ). Assim, seria necessário concluir que o art. $1^{\circ}, \mathbb{\$} 1^{\circ}$ da Lei n. 5.709 (BRASIL, 1971) nunca foi incompatível com a redação originária da Constituição da República, de modo que permaneceria válido na opiniấo da AGU.

O tema voltou a adquirir proeminência no fim dos anos 2010. Em específico, passou a tramitar no Senado o Projeto de Lei n. 2.963/2019, que propóe novos critérios para a aquisição e o uso de imóveis rurais por estrangeiros no Brasil como meio de possibilitar o "ingresso de agroindústrias transnacionais" no país (BRASIL, 2019).

A inovação legislativa mais importante, contudo, foi a Lei n. 13.986 (BRASIL, 2020), que converteu em lei a Medida Provisória n. 897/2019. ${ }^{19}$ Referido diploma, apelidado de "Lei do Agro", trouxe importante inovação redacional ao art. $1^{\circ}, \$ 2^{\circ}$ da Lei n. 5.709 (BRASIL, 1971), após emenda do Deputado Alceu Moreira, que visou alterar as restriçôes para oferta de garantias reais a credores estrangeiros interessados em financiar o agronegócio, justificada pela necessidade de facilitação do crédito, a igualdade entre instituições financeiras nacionais e estrangeiras e a alteraçáo já antes trazida pela Lei n. 13.907/15 (CAMARA DOS DEPUTADOS, 2019). ${ }^{20}$

A emenda trouxe duas alteraçôes. A primeira, já mencionada, é a alteração do art. $1^{\circ}, \$ 2^{\circ}$ da Lei n. 5.709/1971. Já a segunda, complementar àquela, altera o $\$$ $4^{\circ}$ do art. $2^{\circ}$ da Lei n. 6.634 (BRASIL, 1979):

[...] $\$ 2^{\circ}$ As restriçóes estabelecidas nesta Lei não se aplicam: I - aos casos de sucessão legítima, ressalvado o disposto no art. $7^{\circ}$ desta Lei; II - às hipóteses de constituição de garantia real, inclusive a transmissão da propriedade fiduciária em favor de pessoa jurídica, nacional ou estrangeira; III - aos casos de recebimento de imóvel em liquidação de transação com pessoa jurídica, nacional ou estrangeira, ou pessoa jurídica nacional da qual participem, a qualquer título, pessoas estrangeiras físicas ou jurídicas que tenham a maioria do seu capital social e que residam ou tenham sede no exterior, por meio de realização de garantia real, de dação em pagamento ou de qualquer outra forma.

É dizer, passou-se a possibilitar expressamente a constituição de garantia real 19 Em 20 de agosto de 2020 foi promulgada a parte vetada da Lei, após a rejeição do veto presidencial. Os trechos relativos aos vetos năo afetam, contudo, os temas em estudo neste trabalho.

20 Do texto da Emenda para a redação final da Lei, houve apenas alteração de "instituiçáo financeira" para "pessoa jurídica nacional ou estrangeira, ou de pessoa jurídica nacional da qual participem, a qualquer título, pessoas estrangeiras físicas ou jurídicas que tenham a maioria do seu capital social e que residam ou tenham sede no exterior". 
e a transmissão da propriedade fiduciária em favor de pessoa jurídica estrangeira (inc. II), bem como o recebimento de imóvel em liquidação de transação ou por meio da realização de garantia real (inc. III).

A Lei do Agro insere-se num movimento político de modernização da institucionalidade brasileira, incentivando-se a desburocratização do aparato regulatório e o fomento à atividade econômica. ${ }^{21}$ Associa-se, por exemplo, a racionalidade do diploma àquela da Lei de Liberdade Econômica (BRASIL, 2019). ${ }^{22}$ Lida sob essa perspectiva, a Lei do Agro parece instanciar uma hermenêutica pro libertatem também à atividade agroindustrial brasileira, que estimula a realização de mais investimentos e a entrada de novos participantes no mercado nacional, inclusive estrangeiros. $^{23}$

Em tais condiçôes, não há dúvida de que a recente alteração legislativa abriu um importante canal de investimentos na economia brasileira, o que foi tornado possível por meio do acesso a recursos de estrangeiros no mercado de crédito garantido por bens imóveis situados no território brasileiro.

Uma maneira essencial de possibilitá-lo, como a própria Lei dispóe, consiste na previsão da garantia real. Comenta-se abaixo o caso da alienação fiduciária em garantia de bem imóvel, cuja recente alteração legislativa teve enorme repercussão para o incremento da eficiência da economia nacional.

\section{Alienação fiduciária: natureza, funcionamento e análise econômica}

Embora o instituto da alienação fiduciária já exista no ordenamento brasileiro desde a Lei n. 4.728 (BRASIL, 1965), a regulação específica da alienação fiduciária de coisa imóvel deu-se apenas com a promulgação da Lei n. 9.514 (BRASIL, 1997). ${ }^{24}$ O propósito da Lei foi recuperar o dinamismo do mercado imobiliário, estimulando-se a captação de investimentos pelo mercado de capitais e trazendo mais segurança jurídica aos investidores (PONTES; CAMINHA, 2016).

21 Ademais, a Lei está em consonância com o Plano de Valorizaçăo Econômica da Amazônia (Lei 5.173, de 27 de outubro de 1966), que objetiva justamente promover o desenvolvimento autossustentado da economia e o bem-estar social da regiaáo amazônica, de maneira harmônica e integrada na economia nacional (art. $3^{\circ}$ ). Năo por outro motivo, o Plano deve adotar intensiva política de estímulos fiscais, creditícios e outros, com o objetivo de atrair investimentos nacionais e estrangeiros para o desenvolvimento da Regiáo (art. 4o, "i", II).

22 A favor dessa interpretação, cf. VOLTARELLI (2020). Vide, ainda, LUPI (2019).

23 "A positivaçáo da regra da interpretação pro libertatem é assim uma forma de tentar mitigar o desrespeito à livre-iniciativa, ao contrato e à propriedade, cuja proteçăo existe muito mais na lei escrita que no direito efetivamente praticado no País. Por um lado, busca "lembrar" que mesmo a constituiçăo prevê a liberdade de iniciativa como um de seus fundamentos; por outro, por ser voltada nesse contesto às atividades econômicas privadas, determina que nessas se privilegie a escolha dos objetivos particulares, deixando objetivos públicos para a esfera pública e permitindo que o direito privado se torne mais privado" (ACCIOLY apud MARQUES NETO; RODRIGUES JR.; LEONARDO, 2020, p. 41).

24 Art. 22: "A alienação fiduciária regulada por esta Lei é o negócio jurídico pelo qual o devedor, ou fiduciante, com o escopo de garantia, contrata a transferência ao credor, ou fiduciário, da propriedade resolúvel de coisa imóvel”. 
A alienação fiduciária em garantia constitui modalidade do negócio fiduciário pelo qual "uma pessoa (fiduciante) transmite a propriedade de uma coisa ou a titularidade de um direito a outra (fiduciário), que se obriga a dar-lhe determinada destinação e, cumprido esse encargo, retransmitir a coisa ou direito ao fiduciante ou a um beneficiário indicado no pacto fiduciário" (CHALHUB, 2006, p. 38).

Já a propriedade fiduciária se trata, ainda, de modalidade do instituto da propriedade resolúvel. Como explica Orlando Gomes, resolúvel é toda propriedade cujo título constitutivo já estipula em si mesmo a previsão de sua extinção. A causa da extinção - seja ela condição ou termo - vem explícita no título aquisitivo em favor do proprietário diferido, que passa a ter expectativa de direito de aquisiçáo da propriedade do bem, desde que implementada a causa extintiva (GOMES, 2012).

O gênero "propriedade resolúvel", para além de institutos como a retrovenda, o fideicomisso e a venda a contento, contempla a propriedade fiduciária. Trata-se de propriedade resolúvel constituída com o propósito de "garantir uma obrigação assumida pelo alienante em prol do adquirente" (FARIAS; ROSENVALD, 2017, p. 530). Insere-se, assim, dentro do rol de direitos reais com escopo de garantia, como outros já previstos no ordenamento. Como toda garantia, estipula-se em favor do credor-fiduciário, que procura assegurar-se de seu ressarcimento em caso de descumprimento de contrato por parte do devedor-fiduciante.

$\mathrm{Na}$ abalizada opiniáo de Orlando Gomes, a alienaçáo fiduciária caracteriza-se por ser o negócio de garantia no qual "o devedor transmite ao credor a propriedade de mercadorias, admitindo que, se não pagar a dívida, possa ele vendê-las e aplicar o preço da venda no pagamento do seu crédito, ou que, paga, lhe volte a propriedade das mesmas mercadorias". ${ }^{25}$

O devedor-fiduciante transfere, como garantia do crédito, sua propriedade plena sobre determinado bem ou sua titularidade sobre determinado direito ao credor-fiduciário. ${ }^{26}$ Este, por sua vez, promete restituí-lo na propriedade do bem (ou na titularidade dos direitos alienados) táo logo implementada a condição acordada entre as partes; por exemplo, em caso de contratos de mútuo, tão logo pago o valor mutuado.

Assim, a "fidúcia" característica do instituto, na opinião de Paulo Sérgio Restiffe e Paulo Restiffe Neto, consubstancia proteção dúplice. Ao credor fiduciário, garante-se a segurança de poder satisfazer seu crédito com um bem que já integra sua propriedade, em caso de inadimplemento por parte do devedor. Por outro lado, o fiduciante tem a proteção jurídica de reaver o bem ao adimplir a obrigação

$25 \mathrm{Ou}$, ainda: "Em sentido lato, a alienação fiduciária é o negócio jurídico pelo qual uma das partes adquire, em confiança, a propriedade de um bem, obrigando-se a devolvê-la quando se verifique o acontecimento a que se tenha subordinado tal obrigação, ou lhe seja pedida a restituição" (GOMES, 2012, p. 357).

26 Assim, podem ser objeto de alienação fiduciária também os direitos de uso especial para fins de moradia (art. 22, $\$ 1^{\circ}$, inc. II) e direitos reais de uso (inc. III). 
acordada, cuja propriedade se resolverá ao fim do contrato, retornando a si (RESTIFE NETO; RESTIFE, 2009).

A alienação fiduciária representa garantia mais forte do que outras modalidades tradicionais. Isso porque negócios jurídicos como o penhor, caução, anticrese e hipoteca são constituídas na propriedade do devedor (i.e. em coisa alheia), podendo ser objeto de execução em caso de inadimplemento. Mas a propriedade persiste sendo devedor, que só a perde quando efetivada a expropriação judicial em processo executivo. Já a alienação fiduciária em garantia é diferente na medida em que, por meio dela se transfere a propriedade mesma da coisa que servirá de garantia ao contrato, conquanto resolúvel (GOMES, 2012). Assim, não se trata de garantia sobre coisa alheia, mas sobre coisa própria, que passa efetivamente para a titularidade do credor. ${ }^{27}$

No caso da alienação fiduciária de bem imóvel, sua constituição engendra o desdobramento da posse, de modo que o credor-fiduciário se torna o possuidor direto e o devedor-fiduciante o possuidor indireto da coisa imóvel - art. 23, parágrafo único da Lei n. 9.514 (BRASIL, 1997). Também nesse caso, o pagamento da dívida e de seus encargos implica a resolução da propriedade fiduciária, retornando à esfera do devedor fiduciante (art. 25).

Como qualquer outra, a obrigação garantida por alienação fiduciária de bem imóvel pode ser tanto adimplida quanto inadimplida, prevendo a Lei n. 9.514 (BRASIL, 1997) procedimentos distintos em cada caso. No primeiro deles, uma vez concluído o pagamento, passa a correr o prazo de trinta dias para o credor-fiduciário entregar o termo de quitação ao devedor-fiduciante, sob pena de multa (art. 25, $\$ 1^{\circ}$ ). O termo de quitação é relevante, pois sua apresentação perante o agente titular do Registro de Imóveis competente é o que possibilitará o cancelamento do registro da propriedade fiduciária, com o consequente retorno em definitivo do bem imóvel dado em garantia para o patrimônio jurídico do devedor fiduciante (art. 25, $\$ 2^{\circ}$ ).

Por outro lado, se decorrido o prazo para pagamento da dívida sem pagamento, de modo a vencer, iniciar-se-á o procedimento para consolidação da propriedade em nome do credor-fiduciário (art. 26), momento no qual o fiduciante ou seu procurador será intimado para satisfazer a dívida no prazo de quinze dias (art. 26, $\$ 1^{\circ}$ ). Se ainda assim não for adimplida a obrigação acordada, passa a correr novo prazo de quinze dias, agora para que o credor promova leilão público para a alienação do imóvel (art. 27).

27 Afrânio Carlos Camargo Dantzger (2020, p. 181) assevera a importância de não se esquecer "que os dois institutos de garantia - hipoteca e propriedade fiduciária - são diametralmente diferentes entre si, porque, enquanto a hipoteca é apenas um ônus real que grava o imóvel dado em garantia, cuja propriedade permanece no patrimônio do devedor, sendo, portanto, um direito real de garantia sobre coisa alheia ao credor, a propriedade fiduciária é direito real que recai sobre coisa própria do credor, pois a propriedade fiduciária lhe é transferida pelo devedor, fiduciante, por meio do contrato de alienação fiduciária, mediante registro no respectivo Serviço de Imóveis [...]”. 
A Lei n. 9.514 (BRASIL, 1997) prevê dois leilóes. O primeiro exige, para seu sucesso, a oferta de lance com valor igual ou superior ao do imóvel dado em garantia (art. 27, $\mathbb{1}$ ). Já o segundo requer apenas a oferta de lance com valor igual ou superior ao da própria dívida, acrescida de despesas, encargos, tributos e eventuais contribuições condominiais (art. 27, $\$ 2^{\circ}$ ). Por fim, nas situações em que também o segundo leilăo venha a se revelar frustrado por causa da não oferta de lance suficiente, extingue-se a dívida e o credor se torna proprietário do bem (art. 27, $\$ 5^{\circ}$ ).

À semelhança do que ocorre com outras hipóteses de direito real, a Lei n. 9.514 (BRASIL, 1997) veda na alienação fiduciária a instituição do chamado pacto comissório ${ }^{28}$. É dizer, o credor não pode acordar com o devedor que ficará com a coisa adquirida, devendo antes vendê-la para satisfazer o crédito frustrado. Entretanto, a consolidação final da propriedade da coisa imóvel na esfera jurídica do credor é possível quando frustrados ambos os leilóes previstos. Em tais condiçôes, conquanto não desejada pelo ordenamento (daí a vedação do pacto comissório), essa consolidação final na titularidade do credor é admitida. ${ }^{29}$ Prevalece aí o direito ao crédito do credor fiduciário, o qual, aliás, já era proprietário do bem dado em garantia, de modo que passa apenas a ter a propriedade plena (e não mais apenas resolúvel) da coisa. ${ }^{30}$

Náo se duvida dos importantes benefícios econômicos decorrentes do instituto da alienação fiduciária em garantia da coisa imóvel. A criação de modalidades mais eficientes de garantia incentiva uma mais intensa concessão de crédito pelos investidores aos agentes econômicos, pois os credores passam a ter mais segurança quanto à possibilidade de recuperação de seu montante em caso de descumprimento do contrato.

E mais do que isso. Ted Luiz Rocha Pontes e Uinie Caminha (2016) explicam que a alienaçáo fiduciária representa uma alternativa mais interessante para os agentes econômicos do que a garantia hipotecária tradicional. Isso porque, à diferença do que ocorreria com a hipoteca, frequentemente tolhida em sua eficácia por conta da atuação ativista e politizada do Poder Judiciário, a alienação fiduciária parece ter sua dinâmica interna mais respeitada em juízo, o que acarretaria a diminuição na inadimplência dos devedores, verificada empiricamente.

28 "Mas, do mesmo modo que nos direitos pignoratícios, o proprietário fiduciário não pode estipular pacto comissório para ficar com a coisa adquirida. Tem de vendê-la para se satisfazer no produto da venda. Em consequência, jamais adquire a propriedade plena do bem adquirido fiduciariamente, salvo quando, por sentença judicial, a consolidação é determinada” (GOMES, 2012, p. 358).

29 "Uma vez concluído o leiláo, se nấo tiver havido lance vencedor, permanecerá o imóvel no patrimônio do credor sem qualquer ônus, devendo o auto de leilăo ser averbado na matrícula do imóvel, no Registro de Imóveis" (CHALHUB, 2006, p. 294).

30 Como argumenta Marcelo Terra (1998, p. 56) , "na alienação fiduciária em garantia, o credor (fiduciário) já é seu proprietário, o que não ocorre na hipoteca, nem no penhor ou na anticrese; ora, a disposiçáo proibitiva do art. 765 , do Código Civil, veda que o credor hipotecário (por exemplo) se torne o proprietário do bem, mas náo proíbe sua permanência como seu titular de domínio”. 
Como uma possível consequência da aprovação da Lei n. 9.514 (BRASIL, 1997) -embora não se trate de uma relaçáo monocausal, havendo, ainda, vários outros fatores para explicar o fenômeno, os financiamentos imobiliários tanto pelo SBPE (Sistema Brasileiro de Poupança e Empréstimo) quanto pelo SFH (Sistema Financeiro de Habitaçáo) com recursos do FGTS, bem como os créditos imobiliários captados em operaçóes de securitização, tiveram expressivo aumento nos anos subsequentes à promulgação da lei (PONTES; CAMINHA, 2016).

A consolidaçấo do panorama normativo da Lei n. 9.514 (BRASIL, 1997), nesse sentido, teria o efeito de diminuir os custos transacionais incorridos pelos credores quando da concessão de crédito. A menor taxa de inadimplência dos devedores-fiduciantes, em comparação aos devedores de garantias hipotecárias, sinalizaria ao mercado uma maior certeza do sucesso da operaçáo financeira, estimulando o aporte de recursos para operaçóes de crédito garantidas pela alienação fiduciária. Igualmente, a inadimplência do devedor-fiduciante seria menos problemática para o credor, ante a maior certeza da recuperaçáo do crédito concedido.

E assim se chega ao cenário denominado por Juliano J. Assunçáo, Efraim Benmelech e Fernando S. S. Silva de "democratização do crédito". ${ }^{31}$ Referidos autores analisaram as reformas empreendidas no âmbito da Lei n. 10.931 (BRASIL, 2004), que atualizou o Decreto-Lei n. 911 (BRASIL, 1969a) para facilitar aos credores a retomada da posse e a revenda de automóveis financiados no caso de inadimplemento dos devedores fiduciantes. Como consequência da reforma legislativa, devedores com uma maior probabilidade de tornarem-se inadimplentes passaram a ter maiores chances de obter um financiamento de seu automóvel, desde que garantido por alienação fiduciária. ${ }^{32}$

Embora a análise dos autores se dê no contexto da alienação fiduciária de bens móveis, é plausível supor que os mesmos resultados se verifiquem também no âmbito da alienação de bens imóveis. O essencial a se destacar é que o mecanismo da alienaçấo fiduciária representa uma garantia eficiente - ou, ao menos, mais eficiente do que as outras disponíveis - para o credor. Assim, o risco da operação, internalizado pelos agentes econômicos como custos transacionais associados à incerteza da recuperação do crédito em caso de inadimplência, tende a diminuir, ${ }^{33}$ 31 "Perhaps the most important legal feature of debt contracts is the lender's right to repossess assets when borrowers default on promised payments. The legal right to repossess collateral is critical to the provision of credit because it allows creditors to recover, at least partially, the value of their loans" (ASSUNÇĀO; BENMELECH; SILVA, 2014, p. 2661).

32 "Taken together, our results suggest that, after the reform, The Bank expanded financial services to higher-risk and self-employed borrowers and, in some circumstances, also to lower-income borrowers. The evidence shows that the improvement in banks' ability to foreclose and repossess collateral leads to broader access to finance" (ASSUNÇÃO; BENMELECH; SILVA, 2014, p. 2679).

33 Chalhub (2018, p. 491-531) alerta para certa instabilidade trazida por algumas decisôes judiciais: "Algumas das decisóes aqui referidas evidenciam que, apesar de as normas legais sobre esse negócio guardarem fidelidade à dogmática da propriedade resolúvel e à funçáo de garantia a ela atribuída, sua afirmação como novo paradigma no sistema de garantias do direito brasileiro, ainda depende da superação de algumas controvérsias, no processo de construção 
fator que tende, por sua vez, a estimular a expansão do mercado de crédito, especialmente para os devedores antes impedidos de obter financiamentos.

\section{Faixa de fronteira: aspectos geográficos e econômicos}

Como antes anotado, a faixa de fronteira no Brasil encontra-se atualmente regulada pela Lei n. 6.634 (BRASIL, 1979). O diploma define como "área indispensável à Segurança Nacional” a faixa interna de $150 \mathrm{~km}$ paralela à linha divisória terrestre do território nacional. ${ }^{34}$ Trata-se, nas palavras de Renata Furtado, de "área legalmente estabelecida pelo Estado para direcionar um tratamento político diferenciado em relação ao restante do país" (FURTADO, 2015, p. 81-89): uma área sobre a qual paira especial atenção do Estado, por força de seu interesse estratégico na região.

O escopo contemporâneo do especial interesse nas terras da faixa de fronteira pode resumir-se a dois principais fundamentos: a defesa nacional e o desenvolvimento da região. Por um lado, trata-se de território obviamente indispensável à defesa da integridade nacional em vista de sua proximidade com Estados estrangeiros. Já o propósito do desenvolvimento, mais recente, encontra justificativa no fato de que "a faixa de fronteira é atualmente vista como um espaço de integraçáo, um ponto de contato com outros países latino-americanos, como um canal de comunicação entre as diferentes culturas, línguas e costumes" (ANTUNES, 2015, p. 60).

Uma visão tradicional da faixa de fronteira se detinha apenas nas funçóes de garantia de segurança e defesa do território nacional (CARNEIRO FILHO, 2019). Assim, é induvidoso que qualquer Estado deva cuidar de suas fronteiras como meio de assegurar a proteção do território nacional em caso de invasôes dos países vizinhos, por exemplo. Mas também há fatores essenciais relacionados à segurança pública. Para entendê-lo, basta atentar-se para o fato de que o Brasil serve de rota do narcotráfico para produtores de drogas ilícitas sediados em outros países sul-americanos (MEDINA; ALVES, 2018, p. 7-14). É necessária a passagem pela faixa de fronteira para que tais rotas se operacionalizem; ato contínuo, é do interesse da segurança pública nacional o fortalecimento do aparato policial na regiáo para impedir a entrada das substâncias, o que já deixa evidente a essencialidade da faixa de fronteira.

jurisprudencial. Nesse contexto, avulta o questionamento sobre a constitucionalidade do procedimento extrajudicial de consolidaçáo da propriedade e leiláo instituído pelos arts. 26 e 27 da Lei 9.514/1997, suscitado no final do ano de 2017 no Recurso Extraordinário 860.631-SP, com repercussáo geral, de cujo desfecho dependerá a entronização da propriedade fiduciária de bem imóvel no direito positivo brasileiro".

34 Art. 10: "É considerada área indispensável à Segurança Nacional a faixa interna de $150 \mathrm{Km}$ (cento e cinquenta quilômetros) de largura, paralela à linha divisória terrestre do território nacional, que será designada como Faixa de Fronteira". 
Para além das sempre presentes questốes atinentes à defesa nacional (conquanto de importância diminuída em tempos de integraçáo política latino-americana), trata-se de área com importância geográfica e econômica inegável e crescente. A região tornou-se foco de maior atenção por parte do governo federal a partir do início do século XXI, com a criação de políticas públicas como o Programa de Desenvolvimento Social da Faixa de Fronteira (PDFF), concebido com o propósito de intensificar o desenvolvimento da região como centro de integração e contato com outros países da América do Sul (CARNEIRO FILHO, CAMARA, 2019).

Como consequência da visão renovada sobre a faixa de fronteira, a região passou a assumir nova importância para a economia brasileira. A título de exemplo, registre-se que, do volume total de exportaçóes brasileiras, 3,05\% envolviam municípios fronteiriços. O percentual mais que dobrou, passando para $6,5 \%$ no ano de 2013 (ANTUNES, 2015).

Além disso, ao contrário do que se possa imaginar, a exportação da faixa de fronteira náo se destina apenas aos países vizinhos. Embora alguns dos principais parceiros comerciais dos municípios fronteiriços sejam o Paraguai e a Argentina, os principais parceiros de exportação no ano de 2013 foram o Panamá, a China, os Países Baixos e Hong Kong (ANTUNES, 2015). É dizer: a faixa de fronteira brasileira encontra-se vinculada à economia global e não apenas regional, comerciando rotineiramente com países de diversos continentes.

O território da faixa de fronteira brasileira possui extensão total de $17.000 \mathrm{~km}$, compreendendo 588 municípios do país, entre os quais 432 se situam inteiramente dentro da faixa e 156 apenas parcialmente. Isto é, são mais de $10 \%$ do total de 5.570 municípios da Nação. Em termos de área, incluem-se na faixa aproximadamente $16,6 \%$ do território brasileiro (entre os quais, $77 \%$ do território do Estado do Acre) ${ }^{35}$ (AGÊNCIA IBGE NOTÍCIAS, 2020).

A maior área em termos absolutos está no norte do país, com impactos relevantes em 7 estados da Amazônia legal (Mato Grosso, Rondônia, Acre, Amazonas, Roraima, Pará e Amapá), territórios estes que experimentam as externalidades positivas e negativas dos investimentos no agronegócio.

Já em termos relativos a região Sul pode ser considerada a mais afetada, haja vista que a faixa compreende uma parcela significativa dos municípios dos três Estados sulistas. ${ }^{36}$

Veja-se que, dos 399 municípios do Paraná, 138 encontram-se dentro dos limites territoriais da faixa de fronteira, ou $34,5 \%$ da quantidade total. Já o Estado

35 Fonte: https:/g1.globo.com/ac/acre/noticia/2019/04/01/ibge-aponta-que-acre-tem-77percent-do-territorio-na-faixa-de-fronteira.ghtml. Acesso em: 23 jun. 2020.

36 Daí por que, na imagem acima, haver uma densidade muito maior dos pontos representativos dos municípios nas regiôes oeste dos Estados sulistas. 
de Santa Catarina tem 82 municípios dentro da faixa dos 295 totais, o que redunda num percentual de 9,4\%. É o Rio Grande do Sul, contudo, o Estado mais afetado da região, pois possui fronteiras tanto ao sul (com o Uruguai) quanto ao oeste (com a Argentina). Assim, 195 municípios, ou 39,2\% do total de 497, se situam dentro dos limites territoriais da faixa de fronteira.

A regulação especial atinente à área de fronteira com outros países também não é recente no direito brasileiro. Vanderlei Borba registra que a primeira previsão a respeito do tema foi inaugurada pela Lei n. 601/1850, por meio da qual se estabelecia uma zona de dez léguas (ou $66 \mathrm{~km}$ ) como destinada ao estabelecimento de colônias militares (BORBA, 2013). Provisôes com a mesma dimensão foram feitas também sob a égide da Constituiçôes de 1891. A Constituição de 1934 expandiu a faixa para $100 \mathrm{~km}$ ao longo das fronteiras, tendo havido ulterior aumento da faixa de fronteira para $150 \mathrm{~km}$ pela Constituição de 1937 . Ainda segundo Vanderlei Borba, o tema foi desconstitucionalizado a partir da Carta de 1946. Em qualquer caso, manteve-se disciplina especial quanto ao mesmo limite territorial, agora pela Lei n. 2.597/1955. O diploma legislativo que regula a matéria na atualidade é a Lei n. 6.634/1979, que mantém a extensão de $150 \mathrm{~km}$ da faixa de fronteira estabelecida desde $1937 .{ }^{37}$

A Lei n. 6.634 (BRASIL, 1979) prevê regulação especial da aquisição de bens imóveis, em especial com relaçáo a estrangeiros. Assim, o art. $2^{\circ}$ do diploma condiciona as "transaçôes com imóvel rural, que impliquem a obtenção, por estrangeiro, do domínio, da posse ou de qualquer direito real sobre o imóvel” (inc. V) e a "participação, a qualquer título, de estrangeiro, pessoa natural ou jurídica, em pessoa jurídica que seja titular de direito real sobre imóvel rural" (inc. VI), ao assentimento prévio do Conselho de Segurança Nacional, ${ }^{38}$ nome antigo do atual Conselho de Defesa Nacional (renomeado pelo art. 91 da Constituição de 1988). Em não havendo assentimento prévio do órgão, contudo, os atos citados na lei são vedados. $\mathrm{O}$ capital das empresas na faixa de fronteira também deve pertencer majoritariamente a brasileiros (art. $\left.3^{\circ}, \mathrm{I}\right)$. A Lei ainda encontra posterior regulamentação pelo Decreto n. 85.064/1990.

Por fim, registre-se que a Lei n. 8.183 (BRASIL, 1991), que regula as atividades do Conselho de Defesa Nacional, órgão composto pelos Presidentes do Executivo, da Câmara dos Deputados e do Senado, para além de militares e ministros de Estado, ressalta a função do estudo da ocupação da faixa de fronteira para o planejamento e a condução política da estratégia para a defesa nacional. ${ }^{39}$

37 Para um histórico sobre o tema da regulamentaçăo da faixa de fronteiras, vide LACERDA (2012, p. 769-776). 38 Art. 20 "Salvo com o assentimento prévio do Conselho de Segurança Nacional, será vedada, na Faixa de Fronteira, a prática dos atos referentes a: [...]" (g.n.).

39 Art. 5०: "O exercício da competência do Conselho de Defesa Nacional pautar-se-á no conhecimento das situaçōes nacional e internacional, com vistas ao planejamento e à conduçáo política e da estratégia para a defesa nacional. 


\section{Consolidação da propriedade fiduciária pelo credor estrangeiro em faixa de fronteira brasileira: exame da possibilidade jurídica}

Feitas as necessárias consideraçóes nos tópicos anteriores, passa-se a examinar a questáo central do presente trabalho. Conquanto a Lei do Agro tenha alterado expressamente a redação da Lei n. 5.709 (BRASIL, 1971), norma que concerne à aquisição de imóvel rural por estrangeiro residente ou pessoa jurídica estrangeira no País, ela silenciou sobre a eventual possibilidade da consolidação final da propriedade fiduciária pelo estrangeiro na faixa de fronteira. Eis a nova redação do art. $2^{\circ}, \$ 4^{\circ}$ da Lei n. 6.634 (BRASIL, 1979), tal como alterada pela Lei n. 13.986 (BRASIL, 2020):

[...] $\$ 4^{\circ}$ Excetuam-se do disposto nos incisos V e VI do caput deste artigo a hipótese de constituição de garantia real, inclusive a transmissão da propriedade fiduciária, em favor de pessoa jurídica nacional ou estrangeira, ou de pessoa jurídica nacional da qual participem, a qualquer título, pessoas estrangeiras físicas ou jurídicas que tenham a maioria do seu capital social e que residam ou tenham sede no exterior, bem como o recebimento de imóvel rural em liquidação de transação com pessoa jurídica nacional ou estrangeira por meio de realizaçáo de garantia real, de dação em pagamento ou de outra forma (BRASIL, 2020).

$\mathrm{O}$ art. $2^{\circ}, \$ 4^{\circ}$, consigna, portanto, as seguintes exclusões à norma restritiva: (1) a constituição de garantia real; (2) a transmissão da propriedade fiduciária e (3) o recebimento de imóvel rural em liquidação de transação com pessoa jurídica nacional ou estrangeira por meio da realização de garantia real, de dação em pagamento ou de outra maneira.

Entretanto, a transmissão da propriedade fiduciária para credores estrangeiros não equivale à consolidação final da propriedade do bem dado em garantia na esfera de titularidade dos mesmos credores.

Como já explicado acima, a propriedade fiduciária reveste-se de natureza resolúvel, de modo que usualmente jamais se torna plena em favor do fiduciário. Não por outro motivo, o mecanismo usual da alienação fiduciária em garantia de coisa imóvel prevê a realização de dois leilóes extrajudiciais, cujo propósito é vender o bem imóvel e pagar o credor pela dívida garantida, devolvendo, ainda, eventual excedente para o devedor.

Parágrafo único. As manifestaçôes do Conselho de Defesa Nacional serão fundamentadas no estudo e no acompanhamento dos assuntos de interesse da independência nacional e da defesa do estado democrático, em especial aos que se refere: II - quanto à ocupaçáo e à integraçáo das áreas de faixa de fronteira" (g.n.). 
Mas a alteração legislativa nada dispóe a respeito do caso em que não se oferecem ofertas suficientes nos leilóes. De acordo com o procedimento padráo da Lei n. 9.514 (BRASIL, 1997), a propriedade deveria permanecer em definitivo com o credor estrangeiro. Nesse caso, permanece pouco claro se a consolidação final da propriedade pelo credor estrangeiro seria possível na faixa de fronteira.

Abrem-se aí duas linhas possíveis de interpretação. Pode-se, por um lado, considerar que a alteração do art. $2^{\circ}, \$ 4^{\circ}$, da Lei n. 6.634 (BRASIL, 1979) afirmou a validade do instituto da alienação fiduciária na íntegra, incluindo-se aí a possibilidade de o credor estrangeiro permanecer proprietário do bem dado em garantia após a frustração dos leilóes extrajudiciais. Por outro lado, pode-se argumentar que persistiria em qualquer caso impossível a consolidação da propriedade pelo credor estrangeiro, haja vista o interesse público concernente à faixa de fronteira, para além da falta de permissão expressa para tanto. Comenta-se brevemente a respeito de cada uma das linhas interpretativas abaixo.

Como primeira linha argumentativa, contrária à possibilidade de consolidação da propriedade de imóvel em faixa de fronteira em favor de credor estrangeiro, poder-se-ia vislumbrar na controvérsia um caso clássico de antinomia normativa. É dizer, haveria um conflito da vigência de normas aparentemente a dispor de maneiras diferentes e incompatíveis sobre uma mesma situação de fato: a aquisição da plena propriedade por estrangeiro na faixa de fronteira brasileira. Assim, far-se-ia necessário um esforço hermenêutico para superar a percebida incompatibilidade.

Nesse sentido poder-se-ia sugerir a resolução da questão mediante a aplicação do critério hermenêutico "lex specialis derogat legi generali". Tendo em vista "duas normas incompatíveis, uma geral e uma especial (ou excepcional), prevalece a segunda (BOBBIO, 2014, p. 97). É dizer, elimina-se a aparente antinomia por meio da mais atenta verificação do suporte fático objeto de cada norma. Como explica Eros Roberto Grau, em tais casos a antinomia acaba por revelar-se apenas aparente, pois as situaçôes reguladas não são as mesmas. Prossegue o mesmo autor:

Ninguém contesta que a lex specialis prevalece sobre a lex generalis. Trata-se de chave de abóbada do sistema jurídico, indispensável a sua lógica: a lei especial deve prevalecer sobre a geral porque disciplina de forma diferenciada situaçôes específicas que, por algum motivo, devem ser afastadas da incidência da regra geral. Tratando-se de dois suportes fáticos diversos (um da regra geral e outro da regra específica), não há contradição entre eles; uma situação fática subsumir-se-á a uma ou a outra hipótese normativa, jamais às duas, concomitantemente (GRAU, 2005, vol. 28/2005). 
Também na clássica opiniáo de Carlos Maximiliano, a norma especial tem preferência por se relacionar de maneira mais imediata à matéria regulada que a norma geral, devendo ser prestigiada pelo hermeneuta. ${ }^{40}$ Neste caso particular, portanto, a Lei n. 6.634 (BRASIL, 1979) deveria ser considerada especial com relação à Lei n. 9.514 (BRASIL, 1997) em todas as partes nas quais se verificasse incompatibilidade entre as normas, prevaleceria a especial.

$\mathrm{E}$ em que consiste referida incompatibilidade normativa? Ela reside no confronto do art. 27, $\$ \$ 5^{\circ}$ e $6^{\circ}$ da Lei n. 9.514 (BRASIL, 1997) ${ }^{41}$ com o art. $2^{\circ}, \mathrm{V}$, da Lei n. 6.634 (BRASIL, 1979). ${ }^{42}$ Ao considerar-se extinta a dívida da alienação fiduciária, com a expedição de termo de quitação para o devedor-fiduciante, o credor fiduciário estrangeiro acabaria por obter o domínio sobre o imóvel em território da faixa de fronteira, o que permaneceria vedado pela Lei n. 6.634 (BRASIL, 1979).

É certo que houve alteração normativa do art. $2^{\circ}, \$ 4^{\circ}$, da Lei n. 6.634 (BRASIL, 1979). Mas o texto não resolveria a questão, pois ele se refere apenas à transmissão da propriedade fiduciária e não a toda e qualquer propriedade. Assim, o que se pretendeu viabilizar foi apenas a constituição da alienação fiduciária, mas não a consolidação da propriedade plena na mão do credor. Quanto a essa última, permaneceria vigente o regramento especial da Lei n. 6.634 (BRASIL, 1979): estrangeiros dependem de assentimento prévio do Conselho de Defesa Nacional para obtê-la na faixa de fronteira, assentimento sem o qual ela permaneceria vedada. Portanto, prevaleceria a proibição da lei especial.

Assim, confrontado o suporte fático das duas Leis, ocorre situação de aparente antinomia. Enquanto uma não oferece óbice à aquisição de imóveis rurais por estrangeiros por via da realização de uma garantia dada por alienação fiduciária, a outra o condiciona ao assentimento prévio do Conselho de Segurança Nacional, fator que afeta, na prática, a viabilidade do negócio ante o caráter imprevisível do ato, decisão discricionária do órgão (FURTADO, 2010).

A isso se poderia adicionar que a disciplina atinente à faixa de fronteira constitui matéria de segurança nacional, revestindo-se da qualidade de ordem pública. Como se sabe, via de regra a autonomia privada recua diante de ditames da ordem

40 "Se existe antinomia entre a regra geral e a peculiar, específica, esta, no caso particular, tem a supremacia. Preferem-se as disposiçôes que se relacionem mais direta e especificamente com o assunto que se trata: in toto jure generi per speciem derogatur, et illud potissimum habetur quod ad speciem directum est - 'em toda disposiçấo de Direito, o gênero é derrogado pela espécie, e considera-se de importância preponderante o que respeita diretamente à espécie" (MAXIMILIANO, 2018, p. 123).

41 " $\$ 5^{\circ} \mathrm{Se}$, no segundo leilāo, o maior lance oferecido não for igual ou superior ao valor referido no $₫ 2^{\circ}$, considerar-se-á extinta a dívida e exonerado o credor da obrigaçáo de que trata o $\$ 4^{\circ}$.

$\$ 6^{\circ} \mathrm{Na}$ hipótese de que trata o parágrafo anterior, o credor, no prazo de cinco dias a contar da data do segundo leiláo, dará ao devedor quitaçăo da dívida, mediante termo próprio".

42 Art. $2^{\circ}$ : "Salvo com o assentimento prévio do Conselho de Segurança Nacional, será vedada, na Faixa de Fronteira, a prática dos atos referentes a: $\mathrm{V}$ - transaçôes com imóvel rural, que impliquem a obtençấo, por estrangeiro, do domínio, da posse ou de qualquer direito real sobre o imóvel”. 
pública, que fornecem limites objetivos à liberdade negocial (ALMEIDA, 2005). Também nesse caso se daria da mesma maneira: se o Estado brasileiro tem o poder de condicionar o exercício da liberdade por interesse da segurança nacional, com muito maior razão o poderá fazê-lo diante de cidadãos estrangeiros. Tampouco seria medida inédita na história jurídica brasileira, haja vista os vários precedentes legislativos já examinados neste trabalho.

$\mathrm{Na}$ linha oposta, um primeiro e mais óbvio argumento favorável invocará a recente alteração engendrada pela Lei do Agro. Uma das modificaçóes engendradas pelo diploma foi a nova redação do art. $2^{\circ}, \mathbb{S} 4^{\circ}$ da Lei n. 6.634 (BRASIL, 1979), que passou a admitir expressamente a transmissão da propriedade fiduciária para credores estrangeiros. Ao fazê-lo, consignou a aplicabilidade da Lei n. 9.514 (BRASIL, 1997) em toda a sua extensão. E é induvidoso que faz parte da lei de alienação fiduciária a previsão dos dois leilōes extrajudiciais, ao fim dos quais, inexistente lance em valor suficiente para arrematar o bem dado em garantia, este se transmite em definitivo para o credor. $\mathrm{O}$ ato de transmissáo definitiva ao credor, portanto, compóe o próprio instituto da alienação fiduciária, de modo que não se poderia negar ao credor estrangeiro que consolidasse a propriedade nessa hipótese.

Além disso, a alteraçáo do texto da Lei n. 6.634/1979 excetua a necessidade de assentimento prévio do Conselho de Segurança Nacional, "o recebimento de imóvel rural em liquidação de transação com pessoa jurídica nacional ou estrangeira por meio de realizaçáo de garantia real, de dação em pagamento ou de outra forma”. Assim, poder-se-ia interpretar que a consolidação da propriedade fiduciária materializaria a "liquidação de transação" por meio de "realização de garantia real" (no sentido de excuti-la; usando a expressão "realizaçáo" no mesmo sentido que a "realização do ativo" na liquidação de sociedade ou na Lei de Falências) ou de "outra forma" (no sentido da adjudicação pela falta de interessados nos leilóes).

Como argumento adicional, de caráter axiológico, poder-se-ia observar que o direito brasileiro se encontra em momento de incentivo à livre iniciativa e ao fomento da atividade econômica, como representado pela recente aprovação da Lei de Liberdade Econômica (Lei n. 13.874/2019). Vista sob a perspectiva favorável à livre iniciativa, o ingresso de agentes econômicos estrangeiros no mercado tenderia a ser visto como algo positivo, devendo ser estimulado pelo direito e não obstaculizado. Isto se coadunaria com as justificativas da emenda parlamentar que introduziu o dispositivo no Projeto de Lei de Conversão. 


\section{Conclusóes}

Neste artigo, procurou-se abordar o tema da aquisiçáo de bem imóvel por estrangeiros na faixa de fronteira brasileira, especialmente em vista das alteraçóes empreendidas pela recente promulgaçáo da Lei do Agro. Como a Lei náo trouxe disposição expressa a respeito do tema, primeiro, cabe à comunidade jurídica estudar o tema, mesmo como meio de enriquecer o debate que inevitavelmente se travará no contexto judicial.

Náo se pretende dar respostas definitivas sobre um tema ainda em ebulição. Qualquer que seja a resposta da doutrina, deve-se sempre ter em mente as importantes implicaçóes econômicas dela decorrentes. Há de se avaliar, por exemplo, os relevantes custos econômicos incorridos pelos Estados que possuem território situado na faixa de fronteira, que verão restrito um importante mecanismo de concessão de crédito para a atividade econômica. Há muito que se discutir também o possível anacronismo da instituição da faixa de fronteira na atualidade (ou ao menos de sua visão como exclusivamente área de defesa nacional) (FURTADO, 2015), especialmente em vista do fenômeno da integração latino-americana.

Por outro lado, se as repercussôes da interpretação negativa ainda não parecem sobremaneira graves, é porque o mercado de crédito no Brasil ainda se encontra bastante fechado à economia internacional. $\mathrm{O}$ mercado financeiro no Brasil, em especial o bancário, é objeto de uma regulação extremamente protecionista operada pelo Banco Central, o que acarreta a concentração do mercado na mão de poucos e grandes instituiçôes bancárias. ${ }^{43}$

Todavia, caso ocorra uma abertura do mercado de crédito para instituiçôes financeiras estrangeiras questão muito propalada, mas ainda não realizada na prática -, os impactos da limitação imposta pela Lei n. 6.634 (BRASIL, 1979) serão sentidos com muito maior intensidade. É possível que aumente a diferença entre os mercados de crédito para a faixa de fronteira com relação ao restante do território brasileiro. E aí ocorrerá uma intensificação potencialmente injustificada das desigualdades regionais, o que pode inclusive vir a comprometer o "objetivo fundamental" da República de eliminar desigualdades regionais. ${ }^{44}$

Nestes termos, parece mais adequada à mens legislatoris e à interpretação sistemática do ordenamento jurídico a conclusão de que as alteraçóes trazidas pela Lei do Agro admitem a consolidação da propriedade em favor do credor estrangeiro, constituindo esse ato uma "outra forma" de "realização da garantia real", nos termos da Lei n. 6.634/79, tal como alterada pela Lei do Agro.

43 Sobre o tema, cf. o excelente estudo de Maiquel Guilherme Zimann (2017) no contexto do direito concorrencial. 44 Art. 30: "Constituem objetivos fundamentais da República Federativa do Brasil: [...] III - erradicar a pobreza e a marginalizaçáo e reduzir as desigualdades sociais e regionais”. 


\section{Referências}

ACCIOLY, J. C. de A. U. Hermenêutica pro libertatem. In: MARQUES NETO, F. P.; RODRIGUES JR., O. L.; LEONARDO, R. X. Comentários à Lei da Liberdade Econômica - Lei n. 13.874/2019. Sáo Paulo: Revista dos Tribunais, 2020. p. 39-53.

ALMEIDA, R. R. Arbitragem comercial internacional e ordem pública. Dissertação (Mestrado em Direito) - Universidade de São Paulo, São Paulo 2005.

ANJOS, P. C. O novo estatuto do estrangeiro e a impossibilidade da aquisiçáo de terras em regiáo de fronteira por estrangeiros: um novo caso de expulsão. Revista de Direito Brasileira, Florianópolis, v. 1, p. 407-422, jul./dez. 2011.

ANTUNES, E. M. A faixa de fronteira brasileira sob o contexto da integração econômica. Tese (Doutorado em Direito) - Universidade Federal do Paraná, Curitiba, 2015.

ASSUNÇÃO, J. J.; BENMELECH, E.; SILVA, F. S. S. Repossession and the democratization of credit. The Review of Financial Studies, v. 27, n. 9, p. 2661-2689, 2014.

BOBBIO, N. Teoria do Ordenamento Jurídico. 2. ed. São Paulo: Edipro, 2014.

BORBA, V. Fronteiras e faixa de fronteira: expansionismo, limites e defesa. Historice, Rio Grande, v. 4, n. 2, p. 59-78, 2013.

BRASIL. Advocacia-Geral da Uniáo. Parecer n. GQ-181, de 17 de dezembro de 1998. Reexame do Parecer n. AGU/LA-04/94, diante da revogação do art. 171 da Constituição de 1988. Disponível em: https://wwwsistema.planalto.gov.br/asprevweb/exec/parecer/parecerAGU181.html. Acesso em: 24 jun. 2020.

BRASIL. Advocacia-Geral da Uniáo. Parecer n. LA 01 de 19 de agosto de 2010. Aquisição de terras por estrangeiros. Disponível em: http://www.planalto.gov.br/ CCIVIL_03/AGU/PRC-LA01-2010.htm. Acesso em: 24 jun. 2020.

BRASIL. Presidência da República. Casa Civil. Subchefia para Assuntos Jurídicos. Constituição [1988]. Constituição da República Federativa do Brasil de 5 de outubro de 1988. Disponível em: https://bit.ly/3jM4h7M. Acesso em: 6 out. 2020.

BRASIL. Presidência da República. Casa Civil. Subchefia para Assuntos Jurídicos. Decreto-Lei n. 911, de $1^{\circ}$ de outubro de 1969a. Altera a redação do art. 66, da Lei n. 4.728, de 14 de julho de 1965, estabelece normas de processo sobre alienação fiduciária e dá outras providências. Disponível em: https://bit.ly/30PPGkr. Acesso em: 6 out. 2020. 
BRASIL. Presidência da República. Casa Civil. Subchefia para Assuntos Jurídicos. Emenda Constitucional n. 1, de 17 de outubro de 1969b. Edita o novo texto da Constituição Federal de 24 de janeiro de 1967. Disponível em: https://bit. ly/34JLT9k. Acesso em: 6 out. 2020.

BRASIL. Presidência da República. Casa Civil. Subchefia para Assuntos Jurídicos. Lei n. 10.931, de 2 de agosto de 2004. Dispóe sobre o patrimônio de afetaçáo de incorporaçóes imobiliárias, Letra de Crédito Imobiliário, Cédula de Crédito Imobiliário, Cédula de Crédito Bancário e dá outras providências. Disponível em: https://bit.ly/3nvwLFb. Acesso em: 6 out. 2020.

BRASIL. Presidência da República. Secretaria-Geral. Subchefia para Assuntos Jurídicos. Lei n. 13.874, de 20 de setembro de 2019. Institui a Declaração de Direitos de Liberdade Econômica; estabelece garantias de livre mercado; altera as Leis nos 10.406, de 10 de janeiro de 2002 (Código Civil), 6.404, de 15 de dezembro de 1976, 11.598, de 3 de dezembro de 2007, 12.682, de 9 de julho de 2012, 6.015, de 31 de dezembro de 1973, 10.522, de 19 de julho de 2002, 8.934, de 18 de novembro 1994, o Decreto-Lei n. 9.760, de 5 de setembro de 1946 e a Consolidação das Leis do Trabalho, aprovada pelo Decreto-Lei n. 5.452, de $1^{\circ}$ de maio de 1943; revoga a Lei Delegada n. 4, de 26 de setembro de 1962, a Lei n. 11.887, de 24 de dezembro de 2008, e dispositivos do Decreto-Lei n. 73, de 21 de novembro de 1966; e dá outras providências. Disponível em: https://bit.ly/34CLaHe. Acesso em: 6 out. 2020.

BRASIL. Presidência da República. Secretaria-Geral. Lei n. 13.986, de 7 de abril de 2020. Institui o Fundo Garantidor Solidário (FGS); dispóe sobre o patrimônio rural em afetação, a Cédula Imobiliária Rural (CIR), a escrituração de títulos de crédito e a concessão de subvenção econômica para empresas cerealistas e dá outras providências. Disponível em: https://bit.ly/3j2dA2u. Acesso em: 6 out. 2020.

BRASIL. Presidência da República. Casa Civil. Subchefia para Assuntos Jurídicos. Lei n. 4.728, de 14 de julho de 1965. Disciplina o mercado de capitais e estabelece medidas para o seu desenvolvimento. Disponível em: https://bit.ly/3df9zq7. Acesso em: 6 out. 2020.

BRASIL. Presidência da República. Casa Civil. Subchefia para Assuntos Jurídicos. Lei n. 5.709, de 7 de outubro de 1971. Regula a Aquisição de Imóvel Rural por Estrangeiro Residente no País ou Pessoa Jurídica Estrangeira Autorizada a Funcionar no Brasil. Disponível em: https://bit.ly/2SFQK5T. Acesso em: 6 out. 2020.

BRASIL. Presidência da República. Casa Civil. Subchefia para Assuntos Jurídicos. Lei n. 6.634, de 2 de maio de 1979. Dispóe sobre a Faixa de Fronteira, altera o Decreto-lei n. 1.135, de 3 de dezembro de 1970, e dá outras providências. Disponível em: https://bit.ly/31A9iBb. Acesso em: 6 out. 2020. 
BRASIL. Presidência da República. Casa Civil. Subchefia para Assuntos Jurídicos. Lei n. 8.183, de 11 de abril de 1991. Dispóe sobre a organização e o funcionamento do Conselho de Defesa Nacional e dá outras providências. Disponível em: https://bit.ly/3jLuKT8. Acesso em: 6 out. 2020.

BRASIL. Presidência da República. Casa Civil. Subchefia para Assuntos Jurídicos. Lei n. 8.629, de 25 de fevereiro de 1993. Dispóe sobre a regulamentação dos dispositivos constitucionais relativos à reforma agrária, previstos no Capítulo III, Título VII, da Constituição Federal. Disponível em: https://bit.ly/3iSTmIx. Acesso em: 6 out. 2020.

BRASIL. Presidência da República. Casa Civil. Subchefia para Assuntos Jurídicos. Lei n. 9.514, de 20 de novembro de 1997. Dispóe sobre o Sistema de Financiamento Imobiliário, institui a alienaçáo fiduciária de coisa imóvel e dá outras providências. Disponível em: https://bit.ly/2SI229W. Acesso em: 6 out. 2020.

CÂMARA DOS DEPUTADOS. Emenda na Comissão n. 112/2019 MPV 89719. 08 out. 2019. Disponível em: https://bit.ly/3lGJH9N. Acesso em: 20 set. 2020.

CARNEIRO FILHO, C. P.; CAMARA, L. B. Políticas públicas na faixa de fronteira do Brasil: PDFF, CDIF e as políticas de segurança e defesa. Revue Franco-Brésilienne de Géographie, v. 41/2019, n. 41, p. 1-17.

CHALHUB, M. N. Negócio fiduciário. 3. ed. atual. e ampl. Rio de Janeiro: Renovar, 2006.

CHALHUB, M. Alienação fiduciária de bens imóveis: 20 anos de vigência da Lei 9.514/1997. Revista de Direito Imobiliário, São Paulo, v. 84, p. 491-531, jan-jun/2018.

CURY, C. R. J. A constituição de Weimar: um capítulo para a educação. Educaçâo \& Sociedade, Campinas, v. 19, n. 63, p. 83-104, ago. 1998. Disponível em: http://www.scielo.br/scielo.php?script=sci_arttext\&pi$\mathrm{d}=$ S0101-73301998000200006\&lng=pt\&nrm=iso. Acesso em: 30 jun. 2020.

DANTZGER, A. C. C. Alienação fiduciária de bens imóveis: aplicação prática e suas consequências. 5. ed. rev., atual. e ampl. Salvador: JusPodivm, 2020.

FARIAS, C. C.; ROSENVALD, N. Curso de Direito Civil: direitos reais. 13. ed. rev., atual. e ampl. Salvador: JusPodivm, 2017.

FREITAS, G. Lei n. 13.986/2020 autoriza a constituição de propriedade fiduciária de imóveis rurais em favor de estrangeiros. Migalhas, 15 abr. 2020. Disponível em: https://www.migalhas.com.br/depeso/324628/lei-13986-2020-autoriza-a-constituicao-de-propriedade-fiduciaria-de-imoveis-rurais-em-favor-de-estrangeiros. Acesso em: 25 jun. 2020. 
FURTADO, R. 35 anos da Lei da Faixa de Fronteira: avanços e desafios à integração sul-americana. Revista Brasileira de Inteligência, Brasília, DF, n. 9, p. 81-89, maio 2015.

FURTADO, R. S. O assentimento prévio do Conselho de Defesa Nacional na faixa de fronteira. Revista dos Tribunais, São Paulo, v. 897/2010, p. 21-46, jul. 2010.

GOMES, O. Direitos Reais. 21. ed. rev. e atual. Rio de Janeiro: Forense, 2012.

GRAU, E. R. Transporte aéreo de passageiros; dano moral causado a passageiro: prevalência do Código Brasileiro de Aeronáutica sobre o Código de Defesa do Consumidor. Revista de Direito Bancário e do Mercado de Capitais, São Paulo, v. 28/2005, p. 22-26, abr./jun. 2005.

HAGE, F. A. S.; PEIXOTO, M.; VIEIRA FILHO, J. E. R. Aquisição de terras por estrangeiros no Brasil: uma avaliação jurídica e econômica. Brasília, DF: Núcleo de Estudos e Pesquisas do Senado, 2012. Disponível em: https://www12.senado. leg.br/publicacoes/estudos-legislativos/tipos-de-estudos/textos-para-discussao/td-114-aquisicao-de-terras-por-estrangeiros-no-brasil-uma-avaliacao-juridica-e-economica. Acesso em: 23 jun. 2020.

KURTISHI-KASTRATI, S. The effects of foreign direct investments for host country's economy. European Journal of Interdisciplinary Studies, v. 5, n. 1, p. 26$-38,2013$.

LACERDA, M. L. O domínio da União na faixa de fronteiras, o controle das zonas de defesa do País e os novos conceitos de segurança nacional. Doutrinas Essenciais de Direito Internacional, v. 1, p. 769-776, fev. 2012.

LUPI, A. L. P. B. Os contratos comerciais na declaração dos direitos de liberdade econômica (MP n. 881/19). Revista Brasileira de Políticas Públicas, Brasília, DF, v. 9, n. 1, 2019. Disponível em: https://www.publicacoesacademicas.uniceub.br/ RBPP/article/view/6003. Acesso em: 14 out. 2020.

MARINANGELO, R. Critérios para solução de antinomias do ordenamento jurídico. Revista do Instituto dos Advogados de São Paulo, São Paulo, v. 15/2015, p. 216-240, jan./jun. 2015.

MEDINA, T. R.; ALVES, J. Segurança pública na faixa de fronteira entre o Brasil e a Bolívia: o caso de Rio Branco/AC. Arigó: Revista do Grupo PET e Acadêmicos de Geografia da UFAC, Rio Branco, v. 1, n. 1, p. 7-14, jul./dez. 2018.

PONTES, T. L. R.; CAMINHA, U. Uma análise econômica da alienação fiduciária em garantia dos bens imóveis. Scientia Iuris, Londrina, v. 20, n. 1, p. 221-248, abr. 2016. 
PRATES, R. C.; BACHA, C. J. C. Análise da relação entre desmatamento e bem-estar da população da Amazônia Legal. Revista de Economia e Sociologia Rural, Brasília, DF, v. 48, n. 1, p. 165-193, jan./mar. 2010. Disponível em: https://doi. org/10.1590/S0103-20032010000100008. Acesso em: 14 out. 2020.

SARLET, I. W. Os direitos e deveres fundamentais na Constituição da República de Werimar. Consultor Jurídico, 16 ago. 2019. Disponível em: https://www.conjur.com.br/2019-ago-16/direitos-fundamentais-direitos-deveres-fundamentais-constituicao-weimar. Acesso em: 20 set. 2020.

STRECK, L. L.; MORAIS, J. L. B. Ciência Politica e Teoria do Estado. 8. ed. rev. e atual. Porto Alegre: Livraria do Advogado, 2014.

TERRA, M. Alienação Fiduciária de Imóvel em Garantia (Lei n. 9.514/97, primeiras linhas). Porto Alegre: Sergio Antonio Fabris, 1998.

TIMM, L. B.; DRUCK, T. A alienação fiduciária imobiliária em uma perspectiva de direito e economia. In: Latin American and Caribbean Law and Economics Association (ALACDE) Annual Papers. Berkeley, 2007.

VOLTARELLI, V. S. Nova Lei do Agro é grande passo para desburocratização do crédito agrícola. Consultor Jurídico, 16 jun. 2020. Disponível em: https://www. conjur.com.br/2020-jun-16/vitoria-voltarelli-impactos-lei-agro. Acesso em: 25 jun. 2020.

ZIMANN, M. G. O problema da concentraçáo bancária e o desafio da concorrência. Monografia (Graduação em Direito) - Universidade Federal do Paraná, Curitiba, 2017. 